\title{
Perceptions of the Civil Engineering Body of Knowledge Outcomes by Senior Students: Effect of Activities, Internships, and Career Goals
}

\section{Dr. Angela R. Bielefeldt, University of Colorado, Boulder}

Angela Bielefeldt is a professor at the University of Colorado Boulder in the Department of Civil, Environmental, and Architectural Engineering (CEAE). She serves as the ABET assessment coordinator for her department. Bielefeldt is also a licensed P.E. Professor Bielefeldt's research interests in engineering education include service-learning, sustainable engineering, social responsibility, ethics, and diversity. 


\title{
Perceptions of the Civil Engineering Body of Knowledge Outcomes by Senior Students: Effect of Activities, Internships, and Career Goals
}

\begin{abstract}
In the process of updating the Civil Engineering Body of Knowledge Second Edition (BOK2), the ASCE is gathering input from many stakeholders. This paper explores the opinions of students majoring in civil engineering who had completed three to four years of their Bachelor's degree at a research-intensive, public institution and were enrolled in a course where they were learning about the BOK2. Students completed an individual homework assignment where they explored the BOK2; responses from this assignment in 2016 and 2017 were examined $(\mathrm{n}=117)$. When asked to identify the five outcomes that they believed would be the most important in their future civil engineering careers, problem solving, teamwork, communication, and ethics were listed the most often. The outcomes most commonly identified as the least important were humanities, social science, and experiments. The frequency that some outcomes were identified as the most and least important differed based on the students' sub-discipline of interest for their future careers and whether they had engaged in an internship or participated in Engineers Without Borders (EWB). For example, $47 \%$ of EWB participants rated sustainability among the top five most important outcomes, compared to only $19 \%$ of non-EWB participants. A higher percentage of those with internship experiences rated teamwork in the top five important outcomes, and a lower percentage rated attitudes among the five least important outcomes. Those with future career interests in construction engineering rated project management in the top five important outcomes with higher frequency; students with structures career interests believed design to be more important; fewer students with water and/or environmental career aspirations rated globalization among the least important outcomes. Content analysis of an open-ended discussion of the BOK2 found that the majority of students $(93 \%)$ had overall positive statements. Some promoted the inclusion of creativity and innovation as a new outcome. Many commented that they were surprised that attitudes were included, but also deemed attitudes very important. A number liked the emphasis on sustainability, and encouraged even greater focus on this outcome. A few students would have liked more discussion on humanitarian needs and themes. The paper concludes with recommendations for how to use the BOK in teaching.
\end{abstract}

\section{Introduction}

The American Society of Civil Engineers (ASCE) has carefully considered the knowledge, skills, and attitudes (KSA) that individuals should possess when entering into the practice of civil engineering at a professional level. This is intended to coincide with becoming a licensed professional engineer, although some individuals may choose not to pursue licensure (perhaps practicing under an industrial exemption, or due to other circumstances). ASCE has articulated these KSA outcomes in the Civil Engineering Body of Knowledge (CE BOK). The first edition of the CE BOK from 2004 [1] included 15 outcomes (the 11 ABET EAC A to K outcomes [2], 1 depth outcome, and 3 professional breadth outcomes). An updated version of the CE BOK (BOK2) was published in 2008 and was expanded to 24 outcomes, each mapped to a level of achievement in Bloom's cognitive taxonomy that was to be achieved during a Bachelor's degree, during a Master's degree or additional formal education, and/or via on-the-job experience [3]. It 
is expected that the KSA needed for civil engineering professional practice will evolve and change over time; thus, review of the CE BOK on an eight-year cycle has been proposed [4]. ASCE is currently in the process of updating the BOK2 to a third edition (BOK3) [5].

ASCE has taken a scholarly approach to developing and updating its BOK. At each step in the process, ASCE has carefully engaged a variety of stakeholders in the process, to ensure that the $\mathrm{BOK}$ represents the civil engineering profession as a whole. The committee that develops the BOK includes individuals from academia and industry, across the breadth of civil engineering specialty areas. The committee also includes a large number of corresponding members. Drafts of the BOK are released for public comment prior to finalizing the document. The BOK3 process started with benchmarking to explore KSA discussed by a range of engineering disciplines, both domestically and globally [5]. Published literature and position papers were included in this exploration. The goal was to determine if the BOK2 was still appropriate, or if there were outcomes that should potentially be added or removed. The benchmarking step concluded that a third edition of the BOK was needed [5]. This led the BOK3 committee to launch on initial online survey to stakeholders in January to February 2017, with 303 responses received. The range of additional outcomes proposed in the survey were utilized in the current study (see more information in the methods section below).

Engineering students are considered to be one of the stakeholder groups for the CE BOK. Chapter 4 of the BOK2 [3] includes guidance for students. However, student opinions are typically not explicitly considered when formulating the BOK. That is not surprising given that students would not be expected to have a developed perspective on the KSA needed for civil engineers entering practice at a professional level. However, thinking about how students perceive the BOK outcomes and vision may be worthwhile, as these individuals represent the future generation of professional engineers. It is hoped that they will find the vision of civil engineering practice presented in the $\mathrm{CE} \mathrm{BOK}$ to be both inspiring and useful.

Educational theories are relevant to this research in two contexts. First, the extent to which students believe that particular KSA will be important in their future careers will impact their motivation for learning. This extrinsic utility value has been explored in engineering settings [6]. Therefore, if some of the BOK2 outcomes are perceived as unimportant, students' motivation for learning these topics and achieving these outcomes will be reduced. Second, Weidman's [7] Input - Environment - Output (IEO) model of student socialization can contextualize factors that might shape a student's opinion about the importance of different BOK outcomes; Figure 1 summarizes this framework. Important inputs into higher education include the student background in terms of experiences (e.g. family members who are engineers, global travel, work experience in construction) and values. The higher education environment (broadly defined) will interact with these predispositions to result in students' beliefs about the importance of different KSA for their envisioned career (the output). During college, both the normative context (e.g. major, peer group, co-curricular activities) and socialization process (via courses and other interactions) are expected to be important. Professional communities via internships or professional societies can be influential. As well, students' personal communities during college, including friends, family, employers, and co-workers, may be significant in shaping their opinions. Participation in an engineering internship or a particularly impactful co-curricular group such as Engineers Without Borders (EWB) might influence students' attitudes toward 
outcomes that they perceive will be important in their future engineering careers. Further, their mentors across this range of experiences might be very different from their course instructors; for example, EWB typically has a professional mentor for the projects who is from outside academia.

\section{Inputs}

Environment

Socialization via

\section{Undergraduate CE Education}

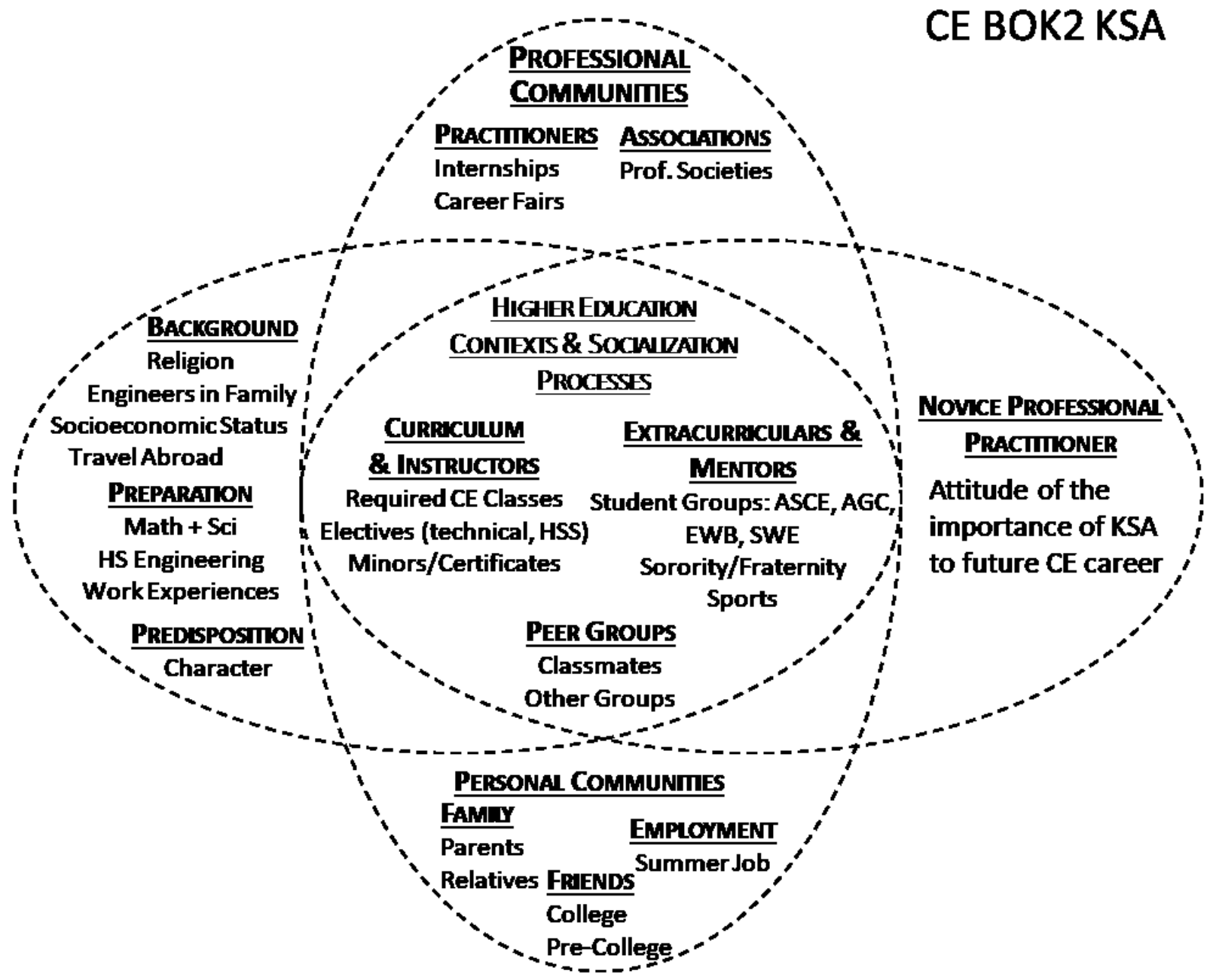

Figure 1. IEO CE Student Socialization Model based on Weidman [7]

\section{Research Questions}

Five research questions are explored in this paper.

RQ1. Which BOK2 outcomes do senior civil engineering students perceive as being the most important to their future careers? Do these opinions vary with demographic factors such as 
gender, if the student previously worked at an engineering internship, EWB participation, or future sub-discipline of interest for their career?

RQ2. Which BOK2 outcomes do senior civil engineering students perceive as being the least important to their future careers? Do these opinions vary with demographic factors?

RQ3. What outcomes do students believe could be important additions to the BOK2 and why?

RQ4. Which among the existing BOK2 outcomes do students believe could be eliminated and why? Which do they believe are particularly important and should be given greater emphasis and why?

RQ5. What overall comments did students have after reading the BOK2?

\section{Methods}

This exploratory study was conducted with a convenience sample of civil engineering (CE) students enrolled in a senior-level professional issues course at a large, public, research-intensive institution. The course is required prior to graduation and scheduled to be taken in the fall of the fourth year of the curriculum. The students taking the course in fall 2016 and fall 2017 were primarily in their seventh semester $(\sim 50 \%)$ or ninth semester $(\sim 50$; about half graduating with their Bachelor's degree after 4.5 years and half graduating with their Bachelor's degree after 5 years). One of the learning objectives for the professional issues course is to describe the knowledge, skills, and attributes required to become a licensed professional engineer (PE), based on the ASCE BOK2. This is a topic early in the semester, with associated lectures and in-class activities, as well as an individual homework assignment. In 2017 the in-class activity asked groups of two to three students to review one of the BOK2 outcomes or a potential new outcome, and comment on a worksheet. This information was used to answer RQ3 and RQ4.

The course homework assignment on the BOK2 asked students to determine which of their courses and co-curricular experiences helped them reach the Bachelor's levels of achievement of the 24 BOK2 outcomes. Next, the students were asked to rank the five outcomes they believed to be the most important in their future civil engineering career, and the five outcomes they believed would be the least important in their future civil engineering career. Each of the outcomes was presented in a table, listed by the title and in the order that they appear in the BOK2. This is important, given that studies have shown that the order of response options may bias survey responses via the process called primacy [8]. In primacy, students select the first reasonable alternative rather than carefully considering all of the presented options. This may be of particular concern given the somewhat long list of 24 outcomes, where outcomes like lifelong learning and ethics are last. The student homework responses were used to answer RQ1 and RQ2. The final question on the homework assignment asked students to summarize their thoughts on the BOK2 in 300 to 500 words. They were prompted to discuss one or more of the following issues: things that surprised them in the BOK2, important outcomes that appear to be missing, whether the vision of civil engineering in the BOK2 aligned with their expectations, and if they were inspired. Emergent content analysis of this final question [9] was used to answer RQ3, RQ4, and RQ5. There were 117 homework assignments that were explored for the research 
in fall 2017 (from among the assignments of the fall 2016 and fall 2017 cohorts of students). This content analysis was conducted after the assignments were graded by the course TA and therefore the research had no impact on student grades in the course.

The demographic variables explored for RQ1 and RQ2 were known based on students' answers to a voluntary survey at the start of the semester where they indicated previous internship experience, participation in undergraduate research or EWB, and the sub-disciplines of interest for a job after graduation. Because some students did not participate in the survey or answer the demographic questions, fewer responses are available for some demographic comparisons ( $\mathrm{n}=$ 93 for sub-discipline of interest for job, for example). Due to somewhat low response numbers, the Fisher's exact test was used to statistically compare the responses between binary demographic groups; this is a more precise version of the chi-square test [10]. For example, the counts for whether or not a female student selected the outcome among the top five most important outcomes were statistically compared to the counts for male students. Statistically significant differences were inferred when two-tailed $p$ values were 0.10 or less.

As a comparative source of data, student responses to the online survey distributed by the college of engineering to all graduating seniors in 2016-2017 were used $(n=51)$. These students should have been enrolled in the professional issues course in fall 2016. Among the questions on that survey, civil engineering students were asked to rate the importance of various outcomes, using a scale of 1 to $5(1=$ not at all important, $2=$ not very important, $3=$ moderately important, $4=$ very important, $5=$ extremely important). The statement just said "importance" (after the students rated how well they felt their engineering education equipped them in each area). This wording difference on the graduating senior survey, as more general "importance" compared to "importance in your future civil engineering career" that was asked on the class homework assignment could have led to different responses. The areas on the graduating senior survey generally mapped to the ABET EAC Criterion $3 \mathrm{~A}$ to $\mathrm{K}$ outcomes [2], and were therefore not a direct match to the BOK2 outcomes. For example, Outcome A, "ability to apply knowledge of math, science and engineering," relates to BOK2 outcomes 1 math and 2 natural science, but also extends beyond those outcomes. Some additional elements queried on the graduating senior survey combined multiple BOK2 outcomes such as "Ability to explain basic concepts in management, business, public policy, and leadership" (a combination of BOK2 outcomes 13, 17, 18 , and 20). Some of the graduating senior survey questions were also outside current BOK2 outcomes, including: "ability to think creatively" and "ability to use the Internet, library, or other sources to research an issue" (which relates to information literacy).

To provide institutional context, students have the option of matriculating directly into the civil engineering major. However, a number of students also transfer into civil engineering, either from an open engineering option in the first year or at other points in the curriculum. The curriculum requires that all students take a fundamental course in five sub-discipline areas of civil engineering, scheduled in fall of the junior year: introduction to construction engineering \& management, fundamentals of environmental engineering, geotechnical engineering 1 , hydraulics, and structural analysis. Students then select second "proficiency" level courses in three sub-discipline areas (e.g. construction equipment and methods, reinforced concrete design, hydrology). Like other engineering majors at this institution, the curriculum has a heavy technical focus with only 18 credits required of humanities and/or social science electives (14\% 
of the total credits required for the degree); the content areas for those courses are not specified. Students were also allowed 6 credits of free electives; these could be applied to certificates or minors, used for study abroad, upper level technical courses, etc. This so-called "new" curriculum was being phased in with the cohort of students taking the professional issues course in fall 2016. Previously, students were required to take a fundamental course in six sub-discipline areas (transportation was also required) and proficiency level courses in four sub-discipline areas. As well, students were required to select one sub-discipline as a concentration area and take two upper-level courses in that area. The old curriculum had no free electives. The new curriculum does not require a concentration (opening those courses to civil engineering technical electives), and added the requirement for the professional issues course. The civil engineering faculty at the institution tend to be heavily research-focused. Among 40 tenured/tenure-track faculty, 33\% had no experience outside academia, 30\% had only 1-2 years working for industry/government, and 20\% had 3-5 years of outside work experience; only 10 were licensed PEs. Notably, all of the faculty in construction had 3-7 years of outside work experience. The program also employs two full-time senior instructors (one construction, one environmental), each licensed PEs with over 10 years of industrial experience. This institutional context is relevant because students' perceptions of the civil engineering discipline are impacted by the education that they experienced, both via required courses and course instructors as role models / mentors [7]. It is also important to consider that conducting this research with students from a single institution limits the generalizability of the findings, due to the bias introduced by the institutional setting.

\section{Results and Discussion}

\section{RQ1. Most Important Outcomes}

Table 1 lists the percentage of the CE students who included each of the 24 BOK2 outcomes among the five most important to their future career. Problem recognition and solving and teamwork were included among the most important by over half of all of the senior CE students. These two outcomes also had the highest average Likert-type importance ratings on the graduating senior survey. Other most important outcomes listed by $25 \%$ or more of the students included communication, ethics, design, project management, and technical specialization. The homework assignment given to the students presented the BOK2 outcomes in a table in numerical order, as shown in Table 1. Thus, response order bias may occur, whereby individuals are more likely to select items listed first in their choices [11], making the inclusion of ethics and teamwork among the top five important outcomes identified by the students particularly noteworthy.

Demographic groups were found to have statistically significant differences in only a few cases. Teamwork was more frequently included among the five most important outcomes among students who had completed an engineering internship (66\% among 87 students) compared to those who had not ( $43 \%$ of 28 students; $p=0.0457$ ). Ethics was more frequently rated in the top five important outcomes among students with job interests in structures (63\% of 32 students versus $33 \%$ of 61 without structures job interest; $\mathrm{p}=0.0082)$. Design was considered differentially important by those with structures interest (59\% among five most important; $p=0.0039)$ and construction interest ( $27 \%$ among five most important; $\mathrm{p}=0.0188)$. Project management was 
rated among the most important outcomes by a higher percentage of students with construction engineering job interests $(55 \%$ among top five; $p=0.003)$ and a lower percentage of students with water/environmental job interests $(26 \%$ in top five among 35 students; $\mathrm{p}=0.0292)$. Leadership was considered among the most important outcomes by more males (32\% of 97 students) than females $(10 \%$ of 20 students; $p=0.057)$. Among the 21 students who had conducted undergraduate research, the only significant differences compared to students without research experience were that fewer rated problem solving among the five most important outcomes $(57 \% ; p=0.100)$ and more rated sustainability among the most important outcomes $(48 \%$; $\mathrm{p}=0.0075)$. Sustainability was rated among the five most important outcomes by more EWB participants ( $44 \%$ of 16 students) than non-EWB participants ( $19 \%$ of 101 students; $\mathrm{p}=0.0398)$.

Table 1. Most and Least Important Outcomes to Future Career among 117 Senior CE Students

\begin{tabular}{|c|c|c|c|c|c|c|c|}
\hline Civil Engineering BOK2 Outcome [3] & $\begin{array}{c}\text { Five } \mathrm{m} \\
\% \\
\text { students }\end{array}$ & $\begin{array}{l}\text { st im } \\
\text { Rank }\end{array}$ & $\begin{array}{l}\text { ortant } \\
\text { Var?* }\end{array}$ & $\begin{array}{c}\text { Five le } \\
\% \\
\text { students }\end{array}$ & $\begin{array}{l}\text { imp } \\
\text { Rank }\end{array}$ & $\begin{array}{l}\text { rtant } \\
\text { Var?* }\end{array}$ & $\begin{array}{c}\text { Survey }^{+} \\
\text {Avg } \\
2016-17\end{array}$ \\
\hline 1. Math & 13 & 13 & & 18 & 11 & & $4.5^{A}$ \\
\hline 2. Natural sciences & 3 & & & 36 & 5 & & $4.5^{A}$ \\
\hline 3. Humanities & 2 & & & 77 & 1 & $\mathrm{~S}$ & -- \\
\hline 4. Social sciences & 2 & & & 69 & 2 & I & -- \\
\hline 5. Material science & 8 & & & 15 & 12 & & -- \\
\hline 6. Mechanics & 14 & 12 & & 11 & 13 & & -- \\
\hline 7. Experiments & 3 & & & 41 & 3 & $\mathrm{~S}$ & 3.7 \\
\hline 8. Problem recognition \& solving & 74 & 1 & $\mathrm{R}$ & 1 & & & 4.7 \\
\hline 9. Design & 38 & 5 & $\mathrm{C}, \mathrm{S}$ & 6 & & EWB & 4.6 \\
\hline 10. Sustainability & 22 & 9 & EWB, R & 5 & & & 4.2 \\
\hline 11. Contemporary issues \& historical perspectives & 1 & & & 39 & 4 & & 4.1 \\
\hline 12. Risk and uncertainty & 13 & 13 & & 7 & & & -- \\
\hline 13. Project management & 37 & 6 & $\mathrm{C}, \mathrm{WE}$ & 3 & & & $4.0^{4}$ \\
\hline 14. Breadth in civil engineering & 18 & 10 & & 26 & 9 & $\mathrm{G}$ & 4.1 \\
\hline 15. Technical specialization & 36 & 7 & & 10 & 14 & & -- \\
\hline 16. Communication & 47 & 3 & & 3 & & & 4.4 \\
\hline 17. Public policy & 3 & & & 28 & 8 & & $4.0^{4}$ \\
\hline 18. Business and public administration & 5 & & & 34 & 6 & $\mathrm{C}, \mathrm{S}$ & $4.0^{4}$ \\
\hline 19. Globalization & 3 & & & 32 & 7 & WE & 4.2 \\
\hline 20. Leadership & 28 & 8 & G & 3 & & & $4.0^{4}$ \\
\hline 21. Teamwork & 60 & 2 & I & 2 & & & 4.8 \\
\hline 22. Attitudes & 9 & & & 25 & 10 & I & -- \\
\hline 23. Lifelong learning & 17 & 11 & & 6 & & & 4.5 \\
\hline 24. Professional and ethical responsibility & 44 & 4 & $\mathrm{~S}$ & 2 & & & 4.5 \\
\hline
\end{tabular}

* Statistical difference based on demographic variables (Fisher's exact test two-tailed $\mathrm{p} \leq 0.10$ ): $\mathrm{G}=$ gender, $\mathrm{I}=$ internship; $\mathrm{C}=$ construction job interest; $\mathrm{S}=$ structures job interest; $\mathrm{WE}=$ water and/or environmental job interest; $\mathrm{EWB}=$ participated in $\mathrm{EWB} ; \mathrm{R}=$ undergraduate research experience;

${ }^{+}$Graduating senior survey items that mapped to multiple BOK2 outcomes; ${ }^{A}$ multiple items from BOK2 that mapped to single survey outcome on ABET Criterion 3a; ${ }^{4}$ all four of these BOK2 outcomes lumped into a single survey item

Differences in opinion among students interested in different sub-disciplines within civil engineering are not particularly unexpected. It is unclear if sub-discipline interests are shaped primarily by course content, course instructors (as role models), or experiences of these subdisciplines outside the classroom via personal contacts (e.g. family member working in that area), internships, undergraduate research, and/or professional societies. Previous research identified differences in the opinions of the importance of BOK2 outcomes among students 
majoring in civil versus environmental or architectural engineering [12]. At many institutions, environmental engineering is merely a sub-discipline within CE rather than a stand-alone major. Within the chemical engineering BOK, differences in the level of achievement among the outcomes are identified for different job sectors, such as a process engineer versus production engineer, and among different industries (e.g. petrochemicals, pulp and paper, academia, government) [13]. Compared to the APPLES dataset from 2009 [14] where fourth-year students rated 20 outcomes, the percentage of students rating various outcomes among the five most important were similar for the majority of the topics (e.g. problem solving, teamwork, ethics, design, life-long learning, math, global context, contemporary issues). The differences compared to the APPLES study were a much lower percentage of the CE students in the current study rating communication within the top five most important outcomes (47\% CE vs $65 \%$ APPLES students) and more CE students rating project management (37\% CE students vs. $12 \%$ management skills among APPLES students) and leadership (28\% CE vs. 14\% APPLES students) in the top five outcomes [14]. The APPLES respondents were primarily majoring in mechanical, computer, and electrical engineering [12].

Some outcomes had importance ratings that were very different compared to ratings of senior civil engineering students from the same institution in 2011 [12]. A much higher percentage of the 2016-2017 students rated teamwork and project management among the five most important outcomes (among 2011 seniors only $26 \%$ and $9 \%$ of rated these among the top five, respectively). A much lower percentage of senior civil engineering students in 2016-2017 rated natural sciences and sustainability among the five most important outcomes (among 2011 seniors, $35 \%$ and $44 \%$ of rated these among the five most important outcomes, respectively). Two key differences are that the 2011 data were generated by a survey in the capstone design course; students gave their opinion in the context of an in-class lecture versus presumably more careful consideration by the 2016-2017 students as part of their homework assignment. The primacy bias of options was likely more acute in the in-class survey in 2011 (due to time constraints and familiarity) and may have impacted the higher rating for natural science (listed as the second outcome on the survey) and sustainability (outcome \#10).

Institutional context is expected to be an important variable in the results. For example, a previous comparison of the perceived importance of BOK2 outcomes between two institutional contexts by Barry et al. [15] found that students at the US Military Academy had higher rankings for lifelong learning and leadership. Institutional context may be important in terms of both differences in the incoming student characteristics (e.g. motivations, preparation, career goals upon entry) and how the institutional environment impacts students.

\section{RQ2. Least Important Outcomes}

The percentage of the senior CE students who rated each BOK2 outcome among the five least important in their future careers are summarized in Table 1. In comparison to the most important ratings, there was more agreement among the students as to the least important outcomes for their future careers. Ten outcomes were rated among the least important by $25 \%$ or more of the senior CE students: humanities, social sciences, experiments, natural sciences, contemporary issues and historical perspective, business, globalization, public policy, breadth in civil engineering, and attitudes. Just because these outcomes were among those considered the least 
important among the 24 BOK2 outcomes, this does not necessarily imply that students believed these outcomes were unimportant. For example, on the graduating senior survey the lowest rated outcome was the ability to design and conduct experiments, which had an average importance rating of 3.7 (where $3=$ moderately important and $4=$ very important); $12 \%$ of the graduating CE students rated the outcome as not very important (1 on the Likert-type scale).

Breadth in civil engineering had the greatest disagreement among the students; it was selected by 21 students as a most important outcome $\left(10^{\text {th }}\right.$ highest ranking) and 30 students as a least important outcome $\left(9^{\text {th }}\right.$ highest ranking). Perhaps some students have an interest solidly within a single sub-discipline area of civil engineering, and therefore believe that knowledge across a breadth of CE is less important in comparison to other outcomes. However, statistically significant differences in importance were not found based on this demographic characteristic. Breadth was identified among the most important outcomes among $12 \%$ of the students who identified a single future job interest area $(n=42)$ versus $24 \%$ of the students who identified multiple specialty areas for future job interests $(n=51 ; p=0.18)$. Breadth in CE was identified as a least important outcome among $24 \%$ of the students who identified a single CE sub-discipline area as their future career interest versus $22 \%$ of the students who identified multiple CE subdiscipline areas as career interests. Further research is needed to explore reasons for the wide disparity in the student responses for this outcome.

Demographic groups differed in the percentage that rated outcomes among the five least important in only a few instances, shown in Table 2. Fewer of the students with an interest in a construction engineering job after college $(n=51)$ rated business among the least important outcomes, compared to those without an interest in working in construction $(n=42)$. A higher percentage of the students with an interest in a structures job $(n=32)$ rated humanities, experiments, and business among the five least important outcomes, compared to students without an interest in a structures related job after graduation $(n=61)$. A lower percentage of the students interested in a post-graduation job related to water and/or environmental $(n=35)$ rated globalization among the five least important outcomes compared to students not interested in these job types $(n=58)$.

Table 2. Demographic Differences in KSA Outcomes Rated Among the Five Least Important

\begin{tabular}{|llll|}
\hline BOK2 Outcome & Group 1, \% & Group 2, \% & $\mathrm{p}$ \\
\hline Math & Undergraduate research, 40 & No research, 14 & 0.0209 \\
Humanities & Structures job goal, 88 & Not structures job, 67 & 0.0449 \\
Social sciences & Internship experience, 73 & No internship, 54 & 0.0631 \\
Mechanics & Undergraduate research, 35 & No research, 6 & 0.0019 \\
Experiments & Structures job interest, 56 & Not structures job, 35 & 0.0757 \\
Design & EWB member, 25 & Not EWB member, 3 & 0.0052 \\
Breadth & Females, 42 & Males, 23 & 0.0905 \\
Business & Construction job interest, 24 & Not construction job, 46 & 0.0273 \\
& Structures job, 53 & Not structures job, 23 & 0.0056 \\
Globalization & Water/environmental job, 21 & Not water/environmental job, 43 & 0.0408 \\
& Undergraduate research, 5 & No research, 38 & 0.0030 \\
Attitudes & Internship experience, 21 & No internships, 39 & 0.0786 \\
\hline
\end{tabular}


While undergraduate research experience was expected to impact ratings of the importance of experiments, it did not (45\% undergraduate researchers rated among least important); but undergraduate researchers did differ in their least important rating of math (higher), mechanics (higher), and globalization (lower). For social science, a higher percentage of students with previous internships rated this as least important compared to those without internship experience; a lower percentage of students who had worked at an internship rated attitudes among the least important outcomes. A higher percentage of female versus male students rated breadth in civil engineering among the least important outcomes, and a higher percentage of those active in EWB rated design among the least important outcomes.

The biggest difference between the least important outcome ratings of students in 2011 and 2016-2017 was that only 4\% of the 2011 students rated experiments among the five least important outcomes [12]. Three other outcomes were also very different in the extent to which students rated them among the five least important outcomes: mechanics (35\% in 2011), lifelong learning (26\% in 2011), and contemporary and historical issues (17\% in 2011).

\section{RQ3. Outcome Additions}

Senior student feedback on ten potential additional BOK outcomes from the in-class exercise is summarized in Table 3. Key references that support the importance of these KSA outcomes are noted. Only the potential outcomes assigned to the students during the in-class exercise are shown, and the list should not be considered exhaustive. The comments reflect the group of two to three students that reviewed each potential outcome, so the results may not be representative of the larger group of students.

In only one case, civic learning, did students feel that it was not important for all CEs to meet some level of the outcome in the cognitive domain. The statements for this outcome included "identify the knowledge and skills necessary for effective civil engineering civic engagement" (Bloom's level 1) and "participate in effective civil engineering civic engagement activities" (Bloom's level 3). It is somewhat unclear how the students defined civic engagement. When describing courses that helped them reach levels of the outcome they cited an optional Habitat for Humanity volunteer activity in a required civil engineering course and elementary school presentation on engineering projects to inspire young students.

For three of the outcomes, potential affective domain outcome statements were also presented to the students. Here, the two students assigned to the interpersonal skills outcome stated that it was not important for all CEs to meet some level of the outcome. A representative affective statement at the lowest level was "Demonstrate sensitivity and empathy to the needs to others, whether in a professional work environment or a public forum. Understand the impact of unconscious bias."

The final open-ended question on the BOK2 homework asked students to comment on various outcomes that they believed were missing and should be added. The students wrote in: creativity/innovation $(n=12)$, elements related to information technology (computer literacy, etc.; $n=7)$, humanitarianism $(n=5)$, safety $(n=2)$, critical thinking $(n=2)$, and interpersonal skills $(n=2)$. Students also suggested additions to the list of important attitudes, including flexibility $(n=2)$, humility, and tact. Some students wrote about the importance of economics $(n=4)$ and PE 
licensure ( $\mathrm{n}=23)$, although they did not necessarily advocate for their addition as stand-alone outcomes in the BOK. For example, one student wrote about the BOK2, "there could have been a greater emphasis on the importance of earning and maintaining a PE license."

Table 3. Student feedback on potential new BOK outcomes

\begin{tabular}{|c|c|c|c|}
\hline $\begin{array}{l}\text { Potential } \\
\text { Outcome * }\end{array}$ & $\begin{array}{l}\text { Student quote: Important for all CE to } \\
\text { meet some cognitive level of this } \\
\text { outcome? Why or why not? }\end{array}$ & $\begin{array}{l}\text { Student quote: Important for } \\
\text { all CE to meet some affective } \\
\text { level of this outcome? }\end{array}$ & Other comments \\
\hline $\begin{array}{l}\text { Civic learning } \\
\text { and } \\
\text { engagement }^{16}\end{array}$ & $\begin{array}{l}\text { No... taking into considering the time } \\
\text { commitment current engineers have, it's } \\
\text { hard for civic learning to occur }\end{array}$ & $\mathrm{N} / \mathrm{A}$ & (none) \\
\hline $\begin{array}{l}\text { Critical } \\
\text { thinking } 16\end{array}$ & $\begin{array}{l}\text { Yes, without critical thinking it shows a } \\
\text { lack of understanding of subject matter. } \\
\text { So critical thinking is a very important } \\
\text { skill. }\end{array}$ & $\mathrm{N} / \mathrm{A}$ & $\begin{array}{l}\text { Not sure how } \\
\text { critical thinking } \\
\text { wasn't on the } \\
\text { original } 24 \text { topics }\end{array}$ \\
\hline $\begin{array}{l}\text { Engineering } \\
\text { economics } 17\end{array}$ & $\begin{array}{l}\text { Yes, more so if going into project } \\
\text { management or the "business" side of } \\
\text { engineering }\end{array}$ & $\mathrm{N} / \mathrm{A}$ & $\begin{array}{l}\text { I think social skills } \\
\text { are more important }\end{array}$ \\
\hline $\begin{array}{l}\text { Information } \\
\text { literacy }{ }^{16}\end{array}$ & $\begin{array}{l}\text { Yes, to avoid failure we need accurate } \\
\text { information }\end{array}$ & N/A & $\begin{array}{l}\text { Is very important } \\
\text { to civil engineers. }\end{array}$ \\
\hline $\begin{array}{l}\text { Information } \\
\text { technology }{ }^{18,19}\end{array}$ & $\begin{array}{l}\text { Yes, IT helps all parts of CE be more } \\
\text { efficient }\end{array}$ & $\mathrm{N} / \mathrm{A}$ & (none) \\
\hline $\begin{array}{l}\text { Infrastructure } \\
\text { systems } 17\end{array}$ & $\begin{array}{l}\text { Yes, it is important because as an } \\
\text { engineer practicing, we need to think } \\
\text { ahead and plan for environmental, } \\
\text { systemic and social changes. }\end{array}$ & N/A & (none) \\
\hline $\begin{array}{l}\text { Interpersonal } \\
\text { skills } 19,20\end{array}$ & Yes & $\begin{array}{l}\text { No, it is not important for all } \\
\text { CE... due to the lack of } \\
\text { interaction for some computer } \\
\text { jobs in CE but consulting is } \\
\text { very interaction based }\end{array}$ & (none) \\
\hline $\begin{array}{l}\text { Legal } \\
\text { Aspects } 17,21\end{array}$ & $\begin{array}{l}\text { Yes... because every engineer must } \\
\text { carry an ethical and honest practice in } \\
\text { their field of work to remain credible, } \\
\text { trust worthy, and reliable. }\end{array}$ & $\mathrm{N} / \mathrm{A}$ & (none) \\
\hline Licensure 22 & $\begin{array}{l}\text { Yes, it is important... especially when } \\
\text { working on certain projects and during } \\
\text { the process of licensure... }\end{array}$ & $\begin{array}{l}\text { Yes, it is important for all CE } \\
\text { to have brief knowledge of the } \\
\text { importance of licensure and } \\
\text { maintaining it }\end{array}$ & (none) \\
\hline Safety 13,17 & $\begin{array}{l}\text { Yes, a complete understanding of safety } \\
\text { regulations and codes is part of an } \\
\text { engineer's ethical responsibility to } \\
\text { protect end-users and laborers on } \\
\text { projects }\end{array}$ & $\begin{array}{l}\text { Yes, especially level } 4 \text { and } 5 . \\
\text { There is always room to } \\
\text { improve in jobsite safety, and } \\
\text { CE are well-positioned to } \\
\text { understand and improve } \\
\text { regulations }\end{array}$ & (none) \\
\hline
\end{tabular}

* Reference that supports potential inclusion of this outcome in the BOK3

Creativity appeared the most often among the open-ended responses as a missing element. An example of a statement related to the importance of creativity is:

I believe that [the BOK2] is quickly becoming outdated and needs to be updated with a third edition. My main reason for thinking this is that this edition does not mention anything about creativity or innovation. It seems to be rather old school and doesn't quite match up to most 
curricula nowadays. I feel that in our education we are constantly striving to solve engineering problems with new unique and innovative techniques....

Another student wrote:

Adding creativity to the BOK is a necessary addition because it is a reminder that we live in an age where computers can solve most of the technical engineering problems. Engineer's add value by their approach to solving problems, and it is important to be reminded to look at problems from many angles.

Beyond the student opinions found in the current study, there is broader support for the importance of creativity as a KSA outcome for engineers. Creativity was among the 20 outcomes listed on the APPLES survey [14], and 30\% of the fourth-year students rated this outcome among the five most important (the $7^{\text {th }}$ highest rated among the outcomes). In a study with EWB student participants, in response to the open-ended question "What do you think an engineer needs to know?", creativity was a theme in $6.6 \%$ of the responses [23]. On the graduating senior survey, the average importance rating of "think creatively" was 4.41 (on a 1 to 5 scale), giving it the $9^{\text {th }}$ highest rank among 23 outcomes and an average importance rating similar to written communication (4.46, ranked 8 th) and higher than some other outcomes currently in the BOK2 (see Table 1; e.g. experiments, globalization). Within the National Society of Professional Engineer's BOK, 13 attributes are listed as necessary for "tomorrow's successful and relevant professional engineer", "creative and innovative" was the third item on the bulleted list [17, p. 12]. Although creativity is not a stand-alone outcome, it is included within the descriptive text of 3 of the 30 outcomes: engineering science, problem recognition and solving, and professional attitudes. Creativity is included within the current Environmental Engineering BOK as part of outcome 7, creative design [24]. The chemical engineering BOK does not include creativity within the outcome statements, but in the body of the report notes "chemical engineering... combines the study and application of chemical and biological processes with physical sciences and creative thought" [13, p. 11]. The vision for mechanical engineering education identified seven targeted areas for change, among them "greater innovation and creativity" and encourage "developing student creativity and innovation skills, through explicit curricular components that emphasize active, discovery-based learning" [20, p. 14]. The International Engineering Alliance (IEA) in its Graduate Attributes and Professional Competencies includes innovation, the "creative use of engineering principles and research-based knowledge in novel ways" as an engineering attribute (EA3) [21, p. 8]. In addition, for all job types, the World Economic Forum anticipates that in 2020 creativity will be the third most important job skill, behind complex problem solving and critical thinking [25]. Thus, a range of engineering students and disciplines believe that creativity is an important skill/attitude.

Elements related to information technology were the second most common outcome that the senior CE students indicated was missing from the BOK2. One example quote from a student is, "While reading through I did notice that the BOK could be expanded to include... technological proficiency. Technological proficiency goes almost without argument in this day and age. As the world moves from paper to computers it would be in the engineering world's best interest to have a good handle on technology." A similar comment from another student was, "There are multiple skills that could be added to the list, including general computing abilities. Every class I have taken here at [institution] has required use of a computer, some more than others.

Regardless, moving forward in the 21 st century, computer skills and innovation are only going to 
become more important." This agrees with feedback on the graduating senior survey where the average importance rating to the statement "Ability to use techniques, skills, and modern engineering tools such as common software programs necessary for engineering practice" was 4.6 (on a 1 to 5 scale). For all job types, information technology was listed as an applied skill whose importance would increase [19].

There were also five $2017 \mathrm{CE}$ students who discussed the desire to see humanitarianism added into the BOK. One student who had been active in Bridges to Prosperity wrote:

I would like to see a section added that talks about humanitarianism in engineering. Something more specific than "giving back" or "contributing to the betterment of society". We must recognize that engineering is only a strong or large profession in developed countries. It is the less developed countries that need engineering ability more than anyone so I would like to see that as an important focus moving forward. Just the way we have standards in the BOK, all humans should have access to a safe and healthy life. The planet cannot move forward in sustainability if only certain parts of the world have the infrastructure to live sustainably.

Among EWB students in response to the open-ended question "What do you think an engineer needs to know?", humanitarian emphasis was a theme in $8.7 \%$ of the student responses (inclusive of terms like compassion, ethics, social responsibility, and how to help) [23]. The lack of caring for others that some perceive during their engineering education may be a contributing factor to why some students leave engineering [26]. Including more discussion of consideration for others, caring, and/or empathy this in the CE BOK might help communicate that the profession truly does hold these values and aspirations.

Although only two students noted interpersonal skills as an outcome that should be added to the BOK, other sources point to the importance of this outcome. The chemical engineering BOK includes "human knowledge", comprised of "listening, interpreting body language, adjusting communication style,.. and cultural factors" [13, p. 15]. Under professional skills, the American Society of Mechanical Engineers (ASME) includes interpersonal skills [20, p. 13]. Across all job types, UNESCO identified interpersonal skills among an important employability trait, and the second most difficult to teach [19, p. 9]. In the open-ended responses of EWB students in response to the question "What do you think an engineer needs to know?", $31.2 \%$ wrote-in a response that mapped to the theme interpersonal skills (e.g. people skills, communication); while communication is an explicit outcome in the BOK2, people skills could be more explicit [23]. It is interesting to note that this was the second most prevalent theme EWB students identified as a gap in their engineering education (13.8\% of respondents) [24]. Interpersonal skills also appear to be among the top 10 important skills for all job types globally in 2020, if people management, coordinating with others, and negotiation are considered among interpersonal skills [25].

Information literacy as an outcome is somewhat encompassed within "Ability to use the Internet, library or other sources to research an issue." This outcome was included on the graduating senior survey, and had an average importance rating by the CE students of 4.4 (on a scale of 1 to 5). Information literacy is one of the intellectual and practical skills considered an "essential learning outcome" for all college students by the Association of American Colleges \& Universities [16]. 
Thus, it appears that a number of additional outcomes may be important for all civil engineers, and therefore may be considered for inclusion in the BOK3. However, some elements may be encompassed within other outcomes. For example, perhaps interpersonal skills can be included in effective teamwork, creativity might be included within both design (as in the environmental engineering BOK [24]) and attitudes, etc. It becomes a balancing act of identifying key areas versus just an overwhelming laundry list. The BOK2 includes 24 outcomes [3]; in comparison, the NSPE BOK includes 30 outcomes [17] and the chemical engineering BOK 63 (41 cognitive outcomes, 18 psychomotor, and 4 affective) [13]. One CE student in this study wrote on their homework assignment, "the list could eventually grow to endless proportions if the goal is to actually describe every last facet that an engineer must encompass."

\section{RQ4. BOK2 Outcomes to Eliminate or Change Emphasis}

During the in-class exercise in 2017, the majority of the BOK2 outcomes (18 of 24) were considered by groups of two to three students. Results are summarized in the Appendix. Among 18 of the existing outcomes in the BOK2 explored by the students, the students felt that all CEs needed to reach some level of the cognitive domain - with the single exception of risk \& uncertainty. Students felt that perhaps the sub-discipline area of construction did not need this knowledge. For eight of the BOK2 outcomes, the students also considered potential affective domain outcome statements; two were deemed not to be needed for all CEs (risk \& uncertainty, leadership). In some cases it was not clear that the students read and/or understood the statements for levels of achievement associated with their outcome. The students' comments on public policy, for example, did not communicate a strong understanding of that outcome.

Two elements in the BOK2 that students widely discussed in a positive way were globalization / the global context of civil engineering $(n=27)$ and sustainability $(n=22)$. Although some commented that these were generally lacking strong focus in their undergraduate education, there was support that the BOK2 included these outcomes. An example quote is:

One of the outcomes, Globalization, surprised me. Not because I don't think it should be an outcome, but because it was one of the outcomes that I view as more than important, but is more than lacking from what I experienced in my undergraduate curriculum. Globalization is especially important as technology increases and we can travel halfway across the world in less than a day. Cultural interaction is at an all-time high, and that is only going to increase. In general, engineering seems to be a major for primarily first world people.... Civil Engineering seems like the discipline that is most fundamental, most integrated through all disciplines - but my classes only prepared me for the first world aspects like structural engineering large buildings, designing water systems for big cities, etc. It was mentioned in a few of my classes, but overall I think our curriculum needs a significant emphasis on engineering in a globalized world.

Another student noted that globalization should be at a higher outcome level for students graduating with a Bachelor's degree.

There were also 30 students who discussed the attitude outcome in the BOK2. Although many students indicated that they were surprised that attitudes were included in the BOK2, the vast majority of the statements were very positive. Other outcomes that were discussed favorably by a 
large number of students were ethics $(n=24)$, communication $(n=20)$, and lifelong learning $(n=10)$.

One outcome that garnered both positive and negative attention was humanities, and to a lesser extent social sciences. There were 16 comments that were generally supportive of this outcome, although some noted that they were initially surprised that it was included but after consideration realized its value. For example: "When I first read the Body of Knowledge, I was very surprised at some of the outcomes that were included. For example, I was not completely sold on the idea that every engineer needs to have Humanities and Social Studies. I also was somewhat unsure of the importance of Business and Public Policy. However, after taking some time to think through each of the outcomes, I can see how every outcome (including the four just listed) play a part." However, two comments indicated that the emphasis on humanities should be "scaled back" and another three students felt that it should be eliminated entirely. This seemed largely driven by negative experiences with their own humanities courses and/or feelings that one's engineering learning should not be "diluted" with taking humanities courses. One student wrote, "I honestly think the humanities requirement is completely wasteful."

The CE breadth and technical specialization outcomes only garnered a little direct attention by the students. Three students noted that they had gained an appreciation for the importance of knowledge across a breadth of civil engineering areas after reading the BOK2. One student indicated that the technical specialization outcome should be set at a higher level of achievement for Bachelor's graduates. Two other students commented that greater acknowledgement of differences among the CE sub-discipline areas should be included in the BOK.

\section{RQ5. Overall Perceptions of the BOK2}

While the majority of the student comments about reading the BOK2 were generally positive $(n=72)$, some were mostly negative $(n=9)$. One student wrote: "bad idea... Should not be continued, redundant, controlling, overwhelming." Another mostly negative response was, "this vision of engineering is complicated; therefore, it is not what I would like to follow closely.... large body of information on mostly common knowledge... [students] do not need to know this information...."

Many of the positive comments cited liking the overall vision of the civil engineering profession and its future. There were 38 students who noted that the document was inspirational or that they felt inspired reading some of its content; another five stated that they were "impressed".

Beyond these overall commentaries on the BOK2 itself, a number of students $(n=18)$ critiqued how their curriculum failed to fulfill the BOK2, for example:

I developed an opinion of how I would change the current course load to better reflect the BOK outcomes. For one, there is too much time spent on basic level math, natural science, social science, and humanities courses to develop enough civil engineering breadth. ... Another area of critique would be the number of social science, humanities, and free credits required by civil engineering students. I am not discrediting or playing down the importance of these courses; however, I think that to achieve the BOK that ASCE wants to meet, these 
kinds of courses need to be scaled back. These kinds of courses could be replaced with other

courses or opportunities to grow those same benefits but do so with an engineering backdrop. The curriculum comments are largely specific to the curriculum that the students encountered in this single program. They generally did not state their comments in that language (e.g. my $C E$ curriculum at $X$ university), but the students are generally only familiar with their own undergraduate experience and not the range of other possibilities that exist.

\section{Discussion}

The research identified differences in the extent to which CE students perceived the 24 outcomes in the BOK2 to be important in their future careers. Using the Weidman IEO student socialization model [7], these importance perceptions were conceptualized as outcomes. Differences in the students' perceptions of the KSA importance may have been due to either input factors to college or a variety of factors during college. College input factors are not known and were not controlled in the study, but could include family members who are engineers, upbringing, etc. Different research, likely with incoming first year students, would be needed to explore the impact of input factors. The required undergraduate curriculum elements at the institution and its overall context would be expected to result in similarities in the perceived importance of the KSA outcomes. Differences could be due to future career plans, elective courses (presumably chosen to align with career aspirations), and co-curricular activities such as engineering internships, undergraduate research experiences, and involvement in EWB. Different future career paths, particularly plans for a structural engineering emphasis versus construction engineering emphasis, impacted the perceived importance of largest number of the 24 BOK2 outcomes. In addition, it is unclear the extent to which the factors that led students to opt in to participation in undergraduate research and/or EWB were the same factors that led to outcome importance perceptions, or whether the experience of engaging in research and/or EWB resulted in the outcome importance perceptions. Distinguishing these correlations versus causations would require additional research, such as a longitudinal study and qualitative methods.

In general, students seemed to appreciate the vision of civil engineering articulated in the BOK2. Assigning selected sections of the BOK2 to the students, such as the vision, guidance to students and selected tables might reduce their feelings of being overwhelmed by a large and detailed document. This supposition is based on the more positive responses to the BOK2 assignment in 2016 and 2017 (89\% positive) compared to 2015 (68\% positive; the students were not given specific guidance on which sections of the BOK2 they should read). Reading and discussing the $\mathrm{BOK}$ might also help to convince the students of the importance of various foundational knowledge (e.g. humanities, social sciences) and/or professional skills, which some students tend to believe are not important for civil engineers. This was the approach taken in the professional issues course, which was tasked with meeting outcomes related to contemporary and historical issues, business and public administration, and public policy (all of these outcomes among the 10 least important, based on the perceptions of the students). Feelings of low importance may translate into low student motivation for learning. Thus, faculty may need to spend extra time making the case for the importance of some outcomes before they can help students advance their knowledge, skills, and/or attitudes in those areas. An introduction to the BOK or its general ideas to first year students may give them a better appreciation of the careful considerations that 
have gone into designing their curriculum and courses. The current curriculum at this institution does introduce students to the BOK2 in the required 1-credit Introduction to CE course.

Perhaps equally important is to convince faculty to read and become familiar with the BOK2. If the students can see the vision of the BOK embraced within their curriculum, courses, and via faculty role models it may help to increase their motivation for learning these topics. In contrast, students were quick to point out discrepancies they felt they had observed - both cases where their curriculum did not seem to communicate the importance of some BOK2 outcomes and the students agreed, or cases where the BOK2 promoted the importance of the outcomes but the students did not feel their curriculum had placed an appropriate emphasis on those outcomes.

\section{Summary}

The results provide insights into the KSA that senior civil engineering students believe to be important to their future careers in civil engineering. In general, there was widespread endorsement that the current BOK2 outcomes are important to some extent for all civil engineers. However, the level of importance varied significantly, with some of the outcomes widely perceived as very important by many students and other outcomes perceived as having low importance across the majority of students. There is some evidence of differences in the opinions among students based on their future career goals, in particular sub-discipline areas of

$\mathrm{CE}$, as well as participation in internships, research, and/or EWB. It is somewhat unclear whether students who perceive certain outcomes as more important are more likely to seek out particular activities, or whether the activities foster feelings of KSA outcome importance among participants. The students also identified some additional outcomes that they felt were important but lacking in the BOK2, including creativity and information technology. These might be candidates for inclusion in the BOK3, either as stand-alone outcomes or incorporated within the context of other outcomes.

\section{References}

[1] American Society of Civil Engineers (ASCE). Civil Engineering Body of Knowledge for the $21^{\text {st }}$ Century: Preparing the Civil Engineer for the Future. ASCE, Reston VA. Jan. 12, 2004. $128 \mathrm{pp}$.

[2] ABET. 2016. Criteria for Accrediting Engineering Programs. Engineering Accreditation Commission (EAC). ABET. Baltimore MD.

[3] American Society of Civil Engineers (ASCE). Civil Engineering Body of Knowledge for the $21^{\text {st }}$ Century: Preparing the Civil Engineer for the Future. Second Edition. ASCE, Reston VA. 2008. $191 \mathrm{pp}$.

[4] A.C. Estes, T.A. Lenox, K.J. Fridley, R.O. Anderson, "Accreditation Insights and the Next Body of Knowledge," Proceedings of the American Society for Engineering Education (ASEE) Annual Conference and Exposition. New Orleans LA, June 26-29, 2016. Paper ID \#14677. 25 pp.

[5] K.J. Fridley, D.B. Hains, L. Nolen, B.E. Barry, B.L. Hartmann, "Is It Time for a Third Edition of the Civil Engineering Body of Knowledge (BOK)?" Proceedings of the American 
Society for Engineering Education (ASEE) Annual Conference and Exposition, Columbus OH, June 24-28, 2017. Paper ID \#18002. 9 pp.

[6] B.D. Jones, M.C. Paretti, S.F. Hein, T.W. Knott, "An Analysis of Motivation Constructions with First-Year Engineering Students: Relationships Among Expectancies, Values, Achievement, and Career Plans," Journal of Engineering Education, 99 (4), 319-336. 2010.

[7] J.C. Weidman, "Socialization of Students in Higher Education: Organizational Perspectives," The SAGE Handbook for Research In Education. 2006. Pp. 253-262.

[8] I. Vriens, G. Moors, J. Gelissen, J.K. Vermunt, "Controlling for Response Order Effects in Ranking Items Using Latent Choice Factor Modeling," Sociological Methods \& Research. 46 (2), 218-241. 2017.

[9] J. W. Creswell, Qualitative Inquiry \& Research Design: Choosing Among Five Approaches, Thousand Oaks, CA: Sage Publications, 2007.

[10] GraphPad Software. QuickCalcs. Analyze a 2x2 contingency table. Available at: https://www.graphpad.com/quickcalcs/contingencyl.cfm [Accessed Oct. 1, 2017].

[11] J.A. Krosnick, D.F. Alwin, "An evaluation of a cognitive theory of response-order effects in survey measurement," Public Opinion Quarterly, 51 (2), 201-219. 1987.

[12] A.R. Bielefeldt, "Similarities and Differences in Architectural, Civil, and Environmental Engineering Students' Perceptions of the Body of Knowledge," Proceedings of the American Society for Engineering Education (ASEE) Annual Conference and Exposition, San Antonio TX, June 10-13, 2012. Paper AC-2012-3785, 19 pp.

[13] American Institute of Chemical Engineers, AIChE. Body of Knowledge for Chemical Engineers. Release 1.0. June 2015. 149 pp.

[14] C.J. Atman, S.D. Sheppard, J. Turns, R.S. Adams, L.N. Fleming, R. Stevens, R.A. Streveler, K.A. Smith, R.L. Miller, L.J. Leifer, K. Yasuhara, D. Lund. 2010. Enabling Engineering Student Success: The Final Report for the Center for the Advancement of Engineering Education. San Rafael, CA: Morgan \& Claypool Publishers. CAEE-TR-10-02. www.engr.washington.edu/caee ISBN 978-1-60845-562-1

[15] B.E. Barry, S.M. Katalenich, B.C. McCoy, "Student Perceptions of the Civil Engineering Body of Knowledge," Proceedings of the American Society for Engineering Education (ASEE) Annual Conference and Exposition. San Antonio TX. June 10-13, 2012. Paper AC 2012-3050. 18 pp. https://peer.asee.org/21945

[16] Association of American Colleges \&Universities, AAC\&U. Essential Learning Outcomes. Available at: https://www.aacu.org/leap/essential-learning-outcomes [Accessed Dec. 30, 2017]

[17] National Society of Professional Engineers, NSPE. Engineering Body of Knowledge. First Edition, 2013. $61 \mathrm{pp}$.

[18] National Academy of Engineering, NAE. Educating Engineers: Preparing $21^{\text {st }}$ Century Leaders in the Context of New Modes of Learning: Summary of a Forum. 2013. National Academies Press, Washington DC. 45 pp.

[19] M. Aring. Report on Skills Gaps. Background paper prepared for the Education for All Global Monitoring Report 2012, United Nations Educational, Scientific and Cultural Organization (UNESCO). 51 pp.

[20] American Society of Mechanical Engineers, ASME. Vision 2030: Creating the Future of Mechanical Engineering Education. September 2012. ASME Board on Education. 16 pp.

[21] International Engineering Alliance, IEA. Graduate Attributes and Professional Competencies. Version 3. 21 June 2013. 16 pp. Available at: 
http://www.ieagreements.org/assets/Uploads/Documents/Policy/Graduate-Attributes-andProfessional-Competencies.pdf [Accessed Dec. 30, 2017].

[22] M. Swenty, B.J. Swenty, "Professional Licensure: The Core of the Civil Engineering Body of Knowledge," Proceedings of the American Society for Engineering Education (ASEE) Annual Conference and Exposition. Columbus OH, June 24-28, 2017. Paper ID \#19425. 14 pp.

[23] K. Litchfield, A. Javernick-Will, "Investigating Gains from EWB-USA Involvement," Journal of Professional Issues in Engineering Education and Practice, 140(1), 9 pp. DOI: 10.1061/(ASCE)EI.1943-5541.0000181.

[24] American Academy of Environmental Engineers, AAEE. Environmental Engineering Body of Knowledge. May 2009. AAEE, Annapolis MD. 82 pp.

[25] World Economic Forum, WEF. The 10 skills you need to thrive in the Fourth Industrial Revolution. 19 Jan 2016, Alex Gray. Available at: https://www.weforum.org/agenda/2016/01/the-10-skills-you-need-to-thrive-in-the-fourthindustrial-revolution// [Accessed Dec. 31, 2017]

[26] A.R. Bielefeld, "Is Engineering About Caring For and Helping Others?" Chapter 4 in: Focus on Educational Research: Practices, Challenges and Perspectives. Ed. Brandon Hernandez. Nova Science Publishers, Inc. 2017. ISBN: 978-1-53610-943-6. pp. 89-118.

\section{Appendix.}

Opinions of Groups of Two to Three Seniors during In-class Exercise on Current Outcomes

\begin{tabular}{|ll|}
\hline BOK2 Outcome & $\begin{array}{l}\text { Student Quotes: Important for all CE to meet some cognitive level of this outcome? Why } \\
\text { or why not? \{Affective domain? Why or why not?\} }\end{array}$ \\
\hline 3. Humanities & $\begin{array}{l}\text { Yes, as civil engineers serving the needs of society, some cognitive skills are called for. } \\
\text { However, in practice they aren't always applied. \{The affective domain is of a little more } \\
\text { importance to civil engineers when compared to the cognitive domain.\} }\end{array}$ \\
& $\begin{array}{l}\text { Yes, it provides for a more well-rounded engineer, allowing said engineer to better work } \\
\text { and design within social constraints (money, political ideologies... etc...) \{Yes, } \\
\text { specifically (2) "discuss the importance of the social sciences and their relationship to CE", } \\
\text { maybe (3), (4), and (5) mainly dependent on the individual engineers' personal drive within } \\
\text { civil. You cannot teach "appreciation"; economics = pretty important, politics = depends on } \\
\text { their role in public relations, etc.\} }\end{array}$ \\
7. Experiments & $\begin{array}{l}\text { Yes, it is important for all CEs... because it aids in developing intuition regarding problems } \\
\text { related to CE. This intuition will increase the engineers' ability to approach and solve }\end{array}$ \\
8. Problem solving \\
complex problems.
\end{tabular}




\begin{tabular}{|c|c|}
\hline BOK2 Outcome & $\begin{array}{l}\text { Student Quotes: Important for all CE to meet some cognitive level of this outcome? Why } \\
\text { or why not? \{Affective domain? Why or why not? }\end{array}$ \\
\hline $\begin{array}{l}\text { 13. Project } \\
\text { management }\end{array}$ & $\begin{array}{l}\text { Yes. Documentation and having all the records are very important in project management. } \\
\text { Also, it can help to communicate and understand the whole project, and divide the big } \\
\text { problems into smaller problems. }\end{array}$ \\
\hline 14. Breadth in $\mathrm{CE}$ & $\begin{array}{l}\text { Yes, because it is critical to understand other disciplines in order to collaborate on design/ } \\
\text { problem solving. Communication between parties hinges on background knowledge. }\end{array}$ \\
\hline $\begin{array}{l}\text { 15. Technical } \\
\text { specialization }\end{array}$ & $\begin{array}{l}\text { Absolutely, you can't be a civil engineer if you don't know the technical specializations of } \\
\text { your focus (hydraulics, geotechnical, etc.) }\end{array}$ \\
\hline $\begin{array}{l}16 . \\
\text { Communication }\end{array}$ & $\begin{array}{l}\text { Yes this outcome is very important. As CEs we will constantly be communicating with the } \\
\text { people around us, whether it be a boss, lawyer, co-worker, etc. \{Yes, because if you are } \\
\text { open to communicate you can relay your ideas and receive criticism better.\} }\end{array}$ \\
\hline 17. Public policy & Yes... because CE designs and projects always affect the public. \\
\hline $\begin{array}{l}\text { 18. Business and } \\
\text { public } \\
\text { administration }\end{array}$ & $\begin{array}{l}\text { At a very simple level of knowledge because business and public administration isn't our } \\
\text { primary job and we can hire people in those fields. }\end{array}$ \\
\hline 20. Leadership & $\begin{array}{l}\text { Yes, because without organization things won't get done. Every group needs a leader or } \\
\text { multiple. \{No, there's a need for leaders and followers.\} }\end{array}$ \\
\hline 21. Teamwork & $\begin{array}{l}\text { Yes, because most real-world projects can only be accomplished by teamwork. \{Yes, some } \\
\text { experience working in teams and learning to communicate effectively is important to } \\
\text { become a professional in industry.\} }\end{array}$ \\
\hline 22. Attitudes & $\begin{array}{l}\text { Yes! To help employees be well rounded and capable of being aware of other team } \\
\text { members. \{Yes! Bringing a positive attitude to the job helps everyone around you.\} }\end{array}$ \\
\hline $\begin{array}{l}\text { 24. Professional } \\
\text { and ethical } \\
\text { responsibility }\end{array}$ & $\begin{array}{l}\text { Yes - it is important for civil engineering to meet some of these levels to function in a } \\
\text { professional setting. The public also relies on engineers being ethically responsible. } \\
\text { \{Ideally yes. It is unrealistic to expect all engineers to meet this level, but in a perfect world } \\
\text { they all would.\} }\end{array}$ \\
\hline
\end{tabular}

